\title{
Assessment of Undiscovered Oil and Gas Resources of the Susitna Basin, Southern Alaska, 2017
}

The U.S. Geological Survey (USGS) recently completed an assessment of undiscovered, technically recoverable oil and gas resources in the Susitna Basin of southern Alaska. Using a geology-based methodology, the USGS estimates that mean undiscovered volumes of about 2 million barrels of oil and nearly 1.7 trillion cubic feet of gas may be found in this area.

\section{Introduction}

The Susitna Basin is a sparsely inhabited region of forested hills and flatlands, situated in southern Alaska about 50 miles (80 kilometers) from Alaska's largest city, Anchorage (figs. 1 and 2). U.S. Geological Survey (USGS) scientists recently finished their first detailed assessment of the undiscovered oil and gas potential of the Susitna Basin at a time when there is significant interest in natural gas supplies of the Anchorage metropolitan area, where natural gas is the principal source of energy for heating and electric power generation in the region.

No commercial petroleum production has been obtained from the Susitna Basin. Few exploratory wells have been drilled, and most of the area is completely unexplored for oil and gas. However, a USGS review of all available geological information from the Susitna Basin indicates the probable existence of technically recoverable oil and gas resources - in other words, those that can be discovered, developed, and produced using current technology — in rocks of Tertiary age (about 66 to 2.6 million years old). The USGS review was done in cooperation with the State of Alaska Department of Natural Resources and included geological field investigations, exploratory wells, seismic data, and gravity and aeromagnetic surveys.

The USGS assessment was based on the geologic elements used to define a Total Petroleum System, including

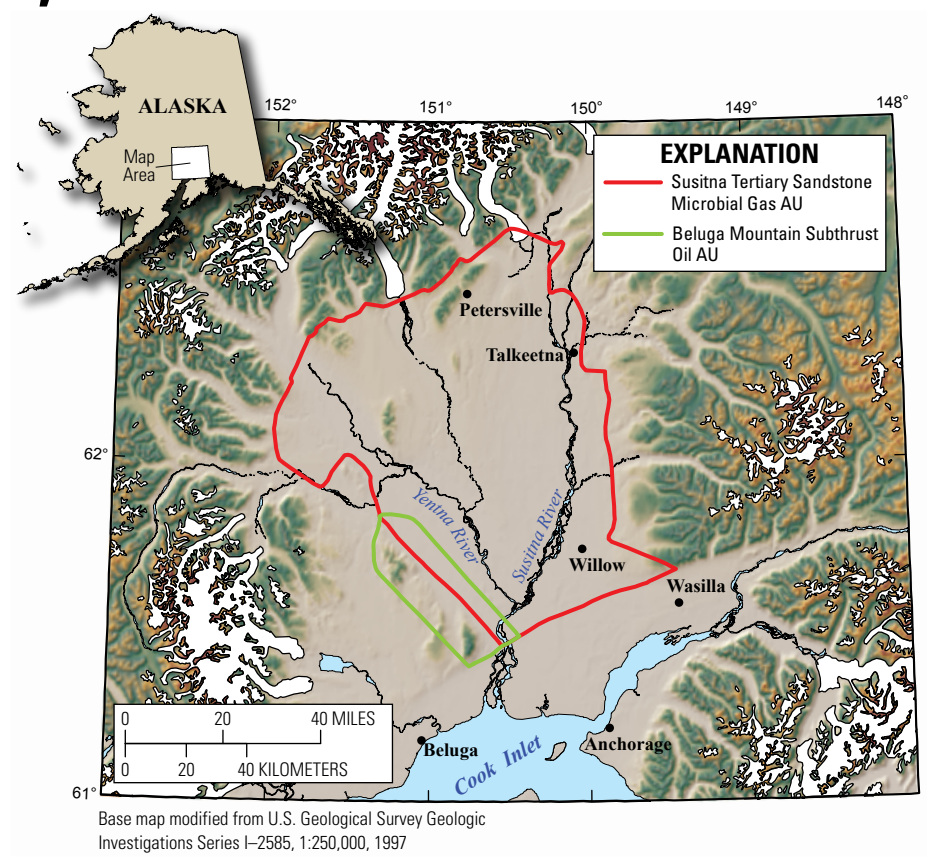

Figure 1. U.S. Geological Survey scientists have estimated undiscovered oil and gas resources within two assessment units (AUs) in the Susitna Basin of southern Alaska. This map shows the AU perimeters, which are based on geological criteria. White areas represent ice, whereas colors show elevations ranging from lowest (tan) to higher (green) to highest (dark brown).

characterization of hydrocarbon source rocks (distribution, thickness, organic richness, thermal maturation, and timing of petroleum generation and migration), reservoir rocks (distribution, quality, and time of formation), and hydrocarbon traps (character and time of formation).

Using this geologic framework, the USGS defined the Susitna Total Petroleum System and two assessment units

Figure 2. The 4,000-square-mile (10,300 square kilometer) Susitna Basin assessment area is characterized by low, forested hills and flatlands. This photograph, looking generally south at an area west of Willow, Alaska, shows a typical landscape. The prominent diagonal line is a remnant of a seismic reflection survey conducted by the oil industry in search of petroleum. Photograph by Richard G. Stanley, U.S. Geological Survey, June 21, 2011. 


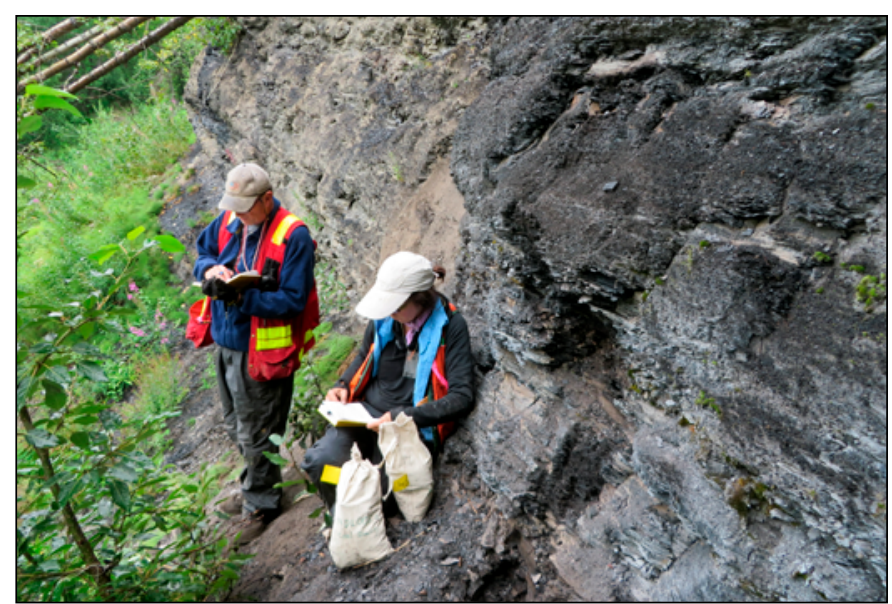

Figure 3. A 4-meter-thick layer of coal in an outcrop located west of Willow, Alaska. Layers of coal similar to this outcrop are possible source rocks of petroleum in the Susitna Basin. Photograph by Richard G. Stanley, U.S. Geological Survey, August 3, 2014.

(AUs) within it - the Susitna Tertiary Sandstone Microbial Gas AU and the Beluga Mountain Subthrust Oil AU. The likely petroleum source rocks in both AUs are coals and shales that are rich in organic matter (fig. 3). Undiscovered petroleum accumulations in both AUs may exist in sandstone and conglomerate reservoirs in structural traps (for example, on anticlines or adjacent to faults) and in stratigraphic traps (for example, where sandstone reservoirs that formed in ancient river channels are confined by impermeable, fine-grained strata that formed on the adjacent floodplains). Key data used to assess the AUs are listed in table 1.

\section{Resource Summary}

The USGS assessment provides forecasts of the volumes of undiscovered petroleum (mainly oil and natural gas) that are technically recoverable. For the Susitna Total Petroleum System, the USGS estimates that total undiscovered natural gas resources range between 0 and 4,672 billion cubic feet of gas (BCFG), with a mean estimate of 1,679 BCFG (table 2). About 99.8 percent, or $1,675 \mathrm{BCFG}$, of the mean natural gas estimate is expected to be found in conventional accumulations in the Susitna Tertiary Sandstone Microbial Gas AU, whereas about 0.02 percent, or $4 \mathrm{BCFG}$, is expected to be found in the Beluga Mountain Subthrust Oil AU.

The USGS estimates that total undiscovered oil resources in the Susitna Total Petroleum System range between 0 and 10 million barrels of oil (MMBO), with a mean estimate of $2 \mathrm{MMBO}$ (table 2). All of the forecasted oil resources are expected to be found in conventional accumulations in the Beluga Mountain Subthrust Oil AU.

\section{Susitna Basin USGS Assessment Team}

Richard G. Stanley (Susitna Task Leader; rstanley@usgs. gov), Christopher J. Potter, Kristen A. Lewis, Paul G. Lillis, Anjana K. Shah, Peter J. Haeussler, Jeffrey D. Phillips, Zenon C. Valin, Christopher J. Schenk, Timothy R. Klett, Michael E. Brownfield, Ronald M. Drake, Thomas M. Finn, Seth Haines, Debra K. Higley, David W. Houseknecht, Phuong A. Le, Kristen R. Marra, Tracey J. Mercier, Heidi M. LeathersMiller, Stanley T. Paxton, Ofori N. Pearson, Marilyn E. Tennyson, Cheryl A. Woodall, and Margarita V. Zyrianova.

\section{For more information, contact:}

USGS Energy Resources Program: https://energy.usgs.gov/

Edit and layout by Katherine Jacques, tables by Cory Hurd

Table 1. Key data for two conventional assessment units in the Susitna Basin of southern Alaska.

[AU, assessment unit; $\mathrm{BCFG}$, billion cubic feet of gas; MMBO, million barrels of oil; -, not applicable]

\begin{tabular}{|c|c|c|c|c|}
\hline $\begin{array}{l}\text { Assessment } \\
\text { input data }\end{array}$ & Minimum & Median & Maximum & $\begin{array}{l}\text { Calculated } \\
\text { mean }\end{array}$ \\
\hline \multicolumn{5}{|c|}{ Susitna Tertiary Sandstone Microbial Gas AU } \\
\hline Number of gas fields & 1 & 40 & 264 & 47.9 \\
\hline $\begin{array}{l}\text { Sizes of gas fields } \\
\text { (BCFG) }\end{array}$ & 3 & 10 & 2,500 & 40.7 \\
\hline AU probability & 0.86 & - & - & - \\
\hline \multicolumn{5}{|c|}{ Beluga Mountain Subthrust Oil AU } \\
\hline Number of oil fields & 1 & 3 & 15 & 3.4 \\
\hline $\begin{array}{l}\text { Sizes of oil fields } \\
\text { (MMBO) }\end{array}$ & 0.5 & 1.5 & 20 & 2.1 \\
\hline AU probability & 0.27 & - & - & - \\
\hline
\end{tabular}

Table 2. Assessment results for conventional oil and gas resources in the Susitna Basin of southern Alaska.

[AU, assessment unit; MMBO, million barrels of oil; BCFG, billion cubic feet of gas; NGL, natural gas liquids; MMBNGL, million barrels of natural gas liquids.

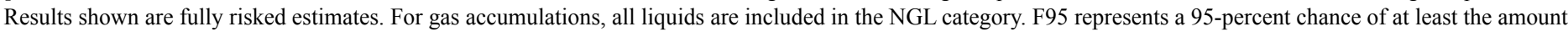
tabulated; other fractiles (F) are defined similarly. Fractiles are additive under the assumption of perfect positive correlation. -, not applicable]

\begin{tabular}{|c|c|c|c|c|c|c|c|c|c|c|c|c|c|c|}
\hline \multirow{3}{*}{$\begin{array}{l}\text { Total petroleum system and } \\
\text { assessment units }\end{array}$} & \multirow{3}{*}{$\begin{array}{c}\text { AU } \\
\text { probability }\end{array}$} & \multirow{3}{*}{$\begin{array}{l}\text { Accumulation } \\
\text { type }\end{array}$} & \multicolumn{12}{|c|}{ Total undiscovered resources } \\
\hline & & & \multicolumn{4}{|c|}{ Oil (MMBO) } & \multicolumn{4}{|c|}{ Gas (BCFG) } & \multicolumn{4}{|c|}{ NGL (MMBNGL) } \\
\hline & & & F95 & F50 & F5 & Mean & F95 & F50 & F5 & Mean & F95 & $\mathrm{F} 50$ & F5 & Mean \\
\hline \multicolumn{15}{|c|}{ Susitna Total Petroleum System } \\
\hline $\begin{array}{l}\text { Susitna Tertiary Sandstone } \\
\text { Microbial Gas AU }\end{array}$ & 0.86 & Gas & - & - & - & - & 0 & 1,310 & 4,651 & 1,675 & 0 & 0 & 0 & 0 \\
\hline $\begin{array}{l}\text { Beluga Mountain Subthrust } \\
\text { Oil AU }\end{array}$ & 0.27 & Oil & 0 & 0 & 10 & 2 & 0 & 0 & 21 & 4 & 0 & 0 & 0 & 0 \\
\hline $\begin{array}{l}\text { Total undiscovered } \\
\text { conventional resources }\end{array}$ & - & - & 0 & 0 & 10 & 2 & 0 & 1,310 & 4,672 & 1,679 & 0 & 0 & 0 & 0 \\
\hline
\end{tabular}

